\title{
Фізична терапія та ерготерапія для осіб похилого віку із хворобою Альцгеймера
}

\author{
УДК 796.035+615.825
}

\section{О. О. Беспалова, М. О. Лянной, В. А. Литвиненко, T. В. Бугаєнко, Т. О. Терещенко}

Сумський державний педагогічний університет імені А.С. Макаренка, Суми, Україна

Національний університет фізичного виховання і спорту України, Київ, Україна

Резюме. Деменція розглядається як стійке порушення когнітивних функцій людини, що виникає внаслідок захворювань або травм головного мозку. Хвороба Альцгеймера є первинною дегенеративною деменцією, яка супроводжується постійним прогресуванням певних порушень і призводить до тотального недоумства. Серед основних клінічних проявів захворювання є: прогресуючі порушення вищих психічних функцій, а саме пам'яті, уваги і мислення, погіршення в некогнітивній сфері і поведінкової діяльності, які дезадаптують людину в соціальному, професійному та побутовому середовищі. Мета. Теоретично обґрунтувати та розробити комплексну програму фізичної терапії та ерготерапії для осіб похилого віку з хворобою Альцгеймера. Методи. Теоретичний аналіз і узагальнення матеріалів науково-методичної літератури; контент-аналіз медичної документації (результатів об'єктивних досліджень, протоколів обстежень, листів спостереження, результатів лабораторних аналізів); педагогічні (спостереження). Результати. У представленій роботі узагальнені дані щодо основних та супутніх порушень у стані здоров'я пацієнтів із хворобою Альцгеймера. Визначено роль, мету та завдання фізичної терапії та ерготерапії у процесі реабілітаційного втручання. Розкрито структуру програми реабілітації та її змістово-процесуальне наповнення. Висновки. З урахуванням основних та супутніх порушень у пацієнтів із хворобою Альцгеймера, у процесі дослідження нами було розроблено комплексну програму фізичної терапії та ерготерапії, яка включала: ранкову гігієнічну гімнастику, лікувальну гімнастику, працетерапію, лікувальну дозовану ходьбу. Метою реабілітаційного втручання було: поліпшення фізичного здоров'я та якості життя осіб похилого віку з хворобою Альцгеймера. Досягнення поставленої мети конкретизується у поставлених завданнях, серед яких: підвищення психоемоційного стану або зниження рівня перезбудження; підвищення рівня добової рухової активності; розвиток основних фізичних якостей: загальної витривалості, м'язової сили, координаційних здібностей (орієнтація у просторі, рівновага) та збільшення амплітуди рухів у суглобах; уповільнення прогресування когнітивних порушень. Дослідження проводилося упродовж 2018-2019 рр. на базі Комунальної установи Сумської обл. ради «Лебединський психоневрологічний інтернат», у якому взяли участь 14 осіб, серед них 9 жінок та 6 чоловіків віком від 65-66 років із хворобою Альцгеймера. Впровадження розробленої нами програми відбувалося упродовж п'яти місяців із дотриманні загальнодидактичних (активності, поступовості, доступності, наочності та ін.) і специфічних принципів, та відповідно до функціональних можливостей пацієнтів (щадному та щадно-тренувальному рухових режимах).

Ключові слова: особи похилого віку, деменція, когнітивні порушення, функціональні обмеження, когнітивна стимуляція, лікувальна фізична культура, працетерапія.

\section{Physical therapy and ergotherapy for the elderly with Alzheimer's disease}

\section{O. O. Bespalova, M. O. Lyannoy, V. A. Lytvynenko, T. V. Bugaienko, T.O. Tereshchenko}

A.S. Makarenko Sumy State Pedagogical University, Sumy, Ukraine National University of Physical Education and Sport of Ukraine, Kyiv, Ukraine

Abstract. Dementia is considered to be a persistent impairment of a person's cognitive function that results from a disease or injury to the brain. Alzheimer's disease is a primary degenerative 
dementia, which is accompanied by the constant progression of certain disorders and leads to total dementia. Among the main clinical manifestations of the disease are: progressive disorders of higher mental functions, namely memory, attention and thinking, deterioration in the non-cognitive sphere and behavioral activity, which maladapt a person in the social, professional and domestic environment. Objective: to theoretically substantiate and develop a comprehensive program of physical therapy and occupational therapy for the elderly with Alzheimer's disease. Methods. During the organization and conduct of scientific research the following methods were used: theoretical analysis and generalization of materials of scientific and methodological literature; content analysis of medical documentation (results of objective research, examination protocols, observation letters, results of laboratory tests); pedagogical (observation). Results. This paper summarizes the data on the main and concomitant health disorders of patients with Alzheimer's disease. The role, purpose and tasks of physical therapy and occupational therapy in the process of rehabilitation intervention are determined. The structure of the rehabilitation program and its content-procedural content are revealed. Conclusions. Taking into account the main and concomitant disorders in patients with Alzheimer's disease, in the course of the study we developed a comprehensive program of physical therapy and occupational therapy, which included: morning hygienic gymnastics, therapeutic gymnastics, occupational therapy, therapeutic dosed walking. The purpose of the rehabilitation intervention was to improve the physical health and quality of life of elderly people with Alzheimer's disease. Achieving this goal is specified in the tasks, including: increasing the psychoemotional state or reducing the level of overexcitation; increasing the level of daily physical activity; development of basic physical qualities: general endurance, muscular strength, coordination abilities (orientation in space, balance) and increase in the amplitude of movements in the joints; slowing the progression of cognitive impairment. The study was conducted during 2018-2019 on the basis of the Municipal Institution of the Sumy Regional Council «Swan Psychoneurological Boarding School», which was attended by 14 elderly people, including 9 women and 6 men aged 65-66 with Alzheimer's disease. The developed program was implemented within five months in compliance with general didactic (activity, gradualness, accessibility, clarity, etc.) and specific principles, and in accordance with the functional capabilities of patients (gentle and gentle-training motor modes).

Keywords: elderly people, dementia, cognitive impairment, functional limits, incongruent symptoms, cognitive stimulation, physical culture, dose management.

Постановка проблеми. Захворювання, що виникають унаслідок ураження головного мозку, різноманітні з точки зору їх ґенезу, клінічних проявів та характеру перебігу, $\epsilon$ економічно обтяжливими для суспільства та системи охорони здоров'я. Вони викликають суттєві труднощі у самих пацієнтів, а також створюють постійне емоційне напруження та виснаження їхнього близького оточення [7].

Розвиваючись на фоні нейродегенеративних захворювань, судинних захворювань головного мозку, а також їх поєднання, проявляються розладами в двох або більше когнітивних сорерах. Одним із найпоширеніших таких захворювань $€$ хвороба Альцгеймера, яка становить близько $70 \%$ усіх випадків деменції. Хвороба Альцгеймера - це первинна дегенеративна деменція, що супроводжується неухильним прогресуванням порушень пам'яті, інтелектуальної діяльності, вищих кіркових фрункцій і призводить до тотального недоумства. У більшості випадків (від 75 до $85 \%$ ) ця патологія починається у віці 45-65 років, проте можливий ранній 31 (до 40 років) і пізніший (старші 65 років) початок захворювання. Середня тривалість хвороби становить 8-10 років [8].

Науковцями зазначається негативна тенденція щодо поширеності хвороби Альцгеймера. Так, за даними ВООЗ на 2013 р. у світі нараховувалося близько 35,6 млн осіб із виявленою деменцією [2]. Статистичні дані на сьогодні вказують, що кількість хворих на деменцію вже налічує близько 50 млн осіб [10]. Основну частку становить населення Азійсько-Тихоокеанського регіону 22,8 млн. Європа має 10,46 млн. хворих, Америка - 10,44 млн, Африка - 4,03 млн [6].

Така тенденція спричиняє значне навантаження на систему охорони здоров'я та економіку навіть високорозвинених країн. Неухильне зростання захворюваності на деменцію може призвести до збільшення кількості хворих у світі із цим синдромом у 2030 р. до $65,7 \mathrm{mлн,} \mathrm{а} \mathrm{в} 2050$ р. до 115,4 млн [1-9].

У 2017 р. у Сумській області паліативної медицини потребувало 48 осіб з хворобою Альцгеймера, які мали VI та VII стадії (із загальних семи) зниження когнітивних функцій за шкалою глобального погіршення когнітивних фрункцій (GlobalDeteriorationScale, GDS) [5].

Аналіз останніх досліджень і публікацій. За класифрікацією Всесвітньої організації охорони здоров'я, до категорії людей похилого віку належать особи віком від 60 до 75 років [4]. Слід відмітити, що у геріатрії та геронтології виправданою $\epsilon$ думка про те, що фрізіологічні та психо- 
логічні риси осіб цього віку суттєво змінюються протягом кожних п'яти років [12].

Україна входить до 30 «найстаріших» країн світу, що пов'язано з тривожною тенденція до зростання кількості осіб похилого віку. Збільшення тривалості життя, а отже і зростання кількості осіб похилого і старечого віку зумовлює поширеність серед популяції основних захворювань, характерних для цього віку, у тому числі, хвороби Альцгеймера. За даними ВООЗ, в 2017 р. у всьому світі нараховувалося близько 50 млн осіб, які страждають на деменцію [13].

Хвороба Альцгеймера - це прогресуюче дегенеративне захворювання мозку, яке характеризується поступовою дегенерацією когнітивних функцій: пам'яті, логічного мислення, мовлення. Вона становить основну частку усіх випадків деменцій (60-80 \%). Люди, які страждають на хворобу Альцгеймера, у середньому живуть 8 років після того, як симптоми стають помітними, проте тривалість може варіюватися від 4 до 20 років залежно від віку особи та умов середовища [3].

За статистикою у осіб пенсійного віку ризик захворіти хворобою Альцгеймера збільшується вдвічі через кожні п'ять років життя. При такій залежності, чим вище кількість літніх людей у віці від 65 років і чим довше живуть ці люди, тим масштабніше поширення хвороби Альцгеймера [9].

Таким чином, не зважаючи на значні наукові досягнення, ця хвороба прогресує, на сьогодні залишається невиліковною, а пацієнти потребують адекватного реабілітаційного втручання 3 боку фахівців мультидисциплінарної команди, зокрема фахівців з фрізичної терапії та ерготерапії, з метою зниження темпів когнітивного дефріциту та покращення їх якості життя.

Мета дослідження - теоретично обгрунтувати та розробити комплексну програму фрізичної терапії та ерготерапії для осіб похилого віку 3 хворобою Альцгеймера.

Методи та організація дослідження. Точний та вчасний діагноз одночасно з раннім початком реабілітаційного втручання сприяє відновленню достатнього рівня компенсації психофрізичних порушень і психосоціальної активності осіб поважного віку з хворобою Альцгеймера та запобігає прогресуванню нейрокогнітивного дефіциту. Комплексний підхід у лікуванні та терапії пацієнтів з деменцією дозволяє забезпечити максимально можливу якість життя і суттєво знизити психологічний і соціальноекономічний тягар, який супроводжує цей розлад для хворої особи, ії оточення та суспільства в цілому.

Наше дослідження проводилося упродовж 2018-2019 рр. на базі Комунальної установи Сумської обласної ради «Лебединський психо- неврологічний інтернат». Комплексну програму фізичної терапії проходило 14 осіб похилого віку, серед них 9 жінок та 6 чоловіків віком від 6566 років, у яких діагностовано хворобу Альцгеймера. 3 метою розробки комплексної програми нами застосовувалися: теоретичний аналіз і узагальнення матеріалів науково-методичної літератури; контент-аналіз медичної документації (результатів об'єктивних досліджень, протоколів обстежень, листів спостереження, результатів лабораторних аналізів); педагогічні спостереження.

У всіх пацієнтів, відповідно до медичної документації, превалює легкий або середній ступінь розумового слабоумства.

Результати дослідження та їх обговорення. Комплексна програма фрізичної терапії та ерготерапії для осіб похилого віку базується на проаналізованому нами досвіді авторів [7, 13, 14] та комплексі показників, отриманих у процесі констатуючого експерименту.

Комплексна програма фрізичної терапії та ерготерапії була спрямована на поліпшення фрізичного здоров'я та якості життя осіб похилого віку 3 хворобою Альцгеймера.

Завданнями програми фрізичної терапії, ерготерапії для осіб похилого віку з хворобою Альцгеймера було: підвищення психоемоційного стану або зниження рівня перезбудження; підвищення рівня добової рухової активності; розвиток основних фрізичних якостей: загальної витривалості, м'язової сили, координаційних здібностей (орієнтація у просторі, рівновага) та збільшення амплітуди рухів у суглобах; уповільнення прогресування когнітивних порушень.

Реалізація програми фрізичної терапії та ерготерапії на практиці відбувалася з урахуванням таких принципів [11]:

1. Ранній початок фрізіотерапевтичних заходів, що дозволяє попередити подальше прогресування захворювання та можливі ускладнення.

2. Комплексне застосування відповідних засобів і методів фізичної терапії та індивідуальний підхід у їх застосуванні.

3. Безперервність реабілітаційного втручання.

4. Доступність фрізичних вправ та посильність фрізичного навантажень для кожного пацієнта.

5. Продуктивна взаємодія усіх членів мультидисциплінарної команди (фахівців з фрізичної терапії, ерготерапії та медичних працівників).

У ході складання комплексної програми фрізичної терапії осіб похилого віку з хворобою Альцгеймера на всіх її етапах враховувався ступінь прояву фрункціональних порушень, рівень толерантності до фізичних навантажень, сукупні захворювання, вік, стать. 
Застосовувалися такі методи організації фізичної терапії:

- за кількістю пацієнтів - індивідуальний;

- за видом діяльності - гімнастичний.

Індивідуальний метод застосовували протягом усього курсу проведення фрізичної терапії: під час встановлення контакту з пацієнтами за допомогою бесіди та у процесі визначення рівня рухової активності, під час проведення процедур ЛГ та масажу.

Гімнастичний метод застосовували у всіх частинах процедури ЛГ, при проведенні спеціальних занять та ранкової гігієнічної гімнастики.

Із контент-аналізу історій хвороб тематичних хворих встановлено, що перші симптоми прояву хвороби Альцгеймера було виявлено після 60 років. Фізіотерапевтичні процедури щодо корекції когнітивних порушень та підвищення рівня рухової активності хворих не проводилися. У більшості історій хвороб зазначено, що пацієнти часто скаржаться на біль, у тому числі на уявний, обумовлений супутніми захворюваннями, які видумують самостійно, але який не мав фактичного підтвердження.

Первинне знайомство з хворими було спрямоване на встановлення дружнього контакту, що ускладнювалося тим, що тематичні хворі в окремих випадках не могли пригадати хто вони. Реалізація комплексної програми фрізичної терапії та ерготерапії стала можливою за підтримки керівництва та персоналу Лебединського психоневрологічного інтернату, у якому на постійній основі, перебувають хворі.

Програму комплексної фрізичної терапії та ерготерапії для осіб похилого віку з хворобою Альцгеймера проводили в умовах спеціалізованого закладу у щадному та щадно-тренувальному рухових режимах. Загальна тривалість реалізації програми становила 5 міс., оскільки за науково встановленими даними поліпшення якості життя осіб з хворобою Альцгеймера достовірно можна зафріксувати лише через 3-6 міс. після початку реабілітаційних заходів.

Під час первинного знайомства 3 хворими піддавали аналізу основні показники стану рухової сорери, що дозволяло охарактеризувати загальний стан статики і локомоції.

До програми фрізичної терапії та ерготерапії для осіб похилого віку з хворобою Альцгеймера було включено:

- ранкову гігієнічну гімнастику (РГГ);

- лікувальну гімнастику (ЛГ);

- працетерапію;

- лікувальну дозовану ходьбу (ЛДХ) (рис. 1).
Ранкова гігієнічна гімнастика

(зранку, щодня, тривалість 10 хв, протягом усього курсу)

Лікувальна гімнастика

у першій половині дня, 2-3 рази на тиждень, тривалість 25-30 хв, протягом усього курсу)

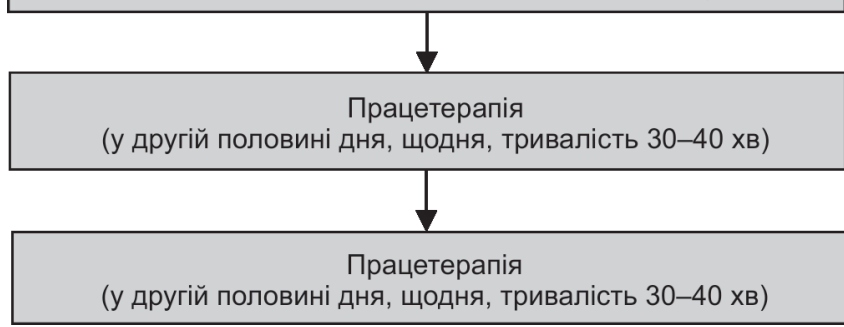

Рисунок 1 - Орієнтовна схема комплексної програми фрізичної терапії та ерготерапії для осіб з хворобою Альцгеймера

У щадному та щадно-тренувальному рухових режимах, які тривали по два з половиною місяці проводили процедури РГГ, ЛГ, ЛДХ.

Фізичне навантаження під час виконання вправ дозували вибором вихідного положення, величиною і кількістю м'язових груп, які брали участь у виконанні вправи, кількістю повторень кожної вправи, амплітудою рухів, темпом виконання, використанням додаткових засобів і предметів.

Ранкову гігієнічну гімнастику проводили щодня з кожним пацієнтом, тривалістю 10 хв. До комплексу РГГ включали 10-12 загальнорозвиваючих, дихальних вправ та вправ на покращення рухових функцій. Комплекси вправ РГГ поступово оновлювалися новими вправами протягом усього періоду проходження курсу.

Лікувальну гімнастику впродовж перших чотирьох тижнів проводили у щадному руховому режимі. Комплекси вправ підбирали індивідуально, залежно від фрізичних можливостей пацієнтів.

Завдання ЛГ у щадному руховому режимі полягали у адаптуванні організму осіб похилого віку з хворобою Альцгеймера, які ведуть малорухомий спосіб життя, до послідовного підвищення фрізичного навантаження, зміцнення м'язового корсета, відновлення монофуункціональних i фрункціональних порушень за наявних супутніх захворюваннях.

У підготовчій частині заняття ЛГ, тривалість якої приблизно становила 3-5 хв, вправи виконувалися із вихідних положень «стоячи» або «сидячи». До виконання пропонувалися загальнорозвиваючі вправи для м'язів шиї, тулуба, верхніх та нижніх кінцівок.

В основній частині заняття ЛГ, приблизна тривалість якої становила 20 хв, виконували вправи 
для відновлення сили м'язів верхніх та нижніх кінцівок, рівноваги та координації.

Для відновлення сили м'язів верхніх та нижніх кінцівок у межах заняття ЛГ хворі виконували вправи з обтяженням масою власного тіла або його сегмента, вправи з подоланням опору, який ми створювали власною рукою. Фізичне навантаження дозували кількістю можливих повторень в одному підході, а вправи з предметами та опором 3 розрахунком 50-60 \% максимально можливого. Кількість повторень вправ у середньому становила 3-4 рази. Відпочинок тривалістю 2-5 хв робили після виконання трьох серій вправ. Під час виконання вправ звертали увагу на темп дихання пацієнта та його загальний стан. Вправи виконували у середньому темпі, у окремих випадках - у повільному, залежно від можливостей пацієнта. Силові вправи виконували на початку основної частини заняття.

Особливу увагу приділяли вправам на покращення рівноваги та координації, адже вони поступово погіршуються 3 прогресуванням деменції. Наслідком цього $€$ часті падіння хворих i, відповідно, травматизація. Ураховуючи вікові особливості пацієнтів, вправи для підвищення рівня розвитку рівноваги виконували із вихідних положень «стоячи» та «сидячи».

Із положення «стоячи» пропонувалися до виконання нескладні вправи із перенесенням ваги тіла з однієї кінцівки на іншу під часу здійснення кроків у різних напрямках, переступання через різноманітні предмети, а також вправи, виконання яких здійснювалося на зменшеній площині опори. За неможливості або складності утримати рівновагу пацієнту дозволяли спиратися на опору (або підтримували пацієнта за руку).

У положенні «сидячи» рекомендували вправи з перенесенням ваги тіла з однієї сідниці на іншу, піднімання зі стільця.

Вправи повторювали 6-8 разів. Кількість повторень та складність вправи змінювали поступово протягом усього курсу залежно від можливостей пацієнта.

У заключній частині заняття ЛГ (приблизна тривалість - 2 хв) застосовували ходьбу на місці з виконанням дихальних вправ. 30 хв.

Загальна тривалість заняття ЛГ становила

ЛГ $з$ дозволу керівництва проводили 2-3 рази на тиждень у першій половині дня, у час, вільний від обов'язкових процедур, передбачених розкладом спеціалізованого закладу.

Заняття працетерапією середньою тривалістю від 30 до 40 хв проводили щодня. Заняття булі спрямовані на покращення дрібної моторики та підвищення психоемоційного стану осіб з хворобою Альцгеймера. У межах заняття хворим пропонували виконання активних вправ пальцями, у тому числі з еластичною гумою, малювання, вирізання крупних фрігур з різних видів паперу, складання пазлів великого та середнього розміру загальною кількістю не більше 20, перекладання предметів різної форми та розмірів.

Лікувальна дозована ходьба була спрямована на збільшення загальної витривалості осіб з хворобою Альцгеймера. ЛДХ, з урахуванням можливостей спеціалізованого закладу, проводили по прямій та похилій поверхнях у коридорі або на вулиці, на сходах. Додатково для покращення рівноваги та координації під час ходьби виконували ходу вперед і назад, перехресним кроком, по прямій ліній, по «коридору», що звужується, та ін. Тривалість ЛДХ визначали індивідуально, залежно від можливостей пацієнта. Безперервну ходьбу починали з 3-5 хв і поступово її збільшували до 30 хв. За необхідності під час ходьби окремим хворим надавали підтримку. ЛДХ дозволяє не тільки тренувати витривалість та покращувати рівновагу і координацію, але й сприяє поліпшенню орієнтації в просторі та пам'яті.

Висновки. Деменція розглядається як стійке порушення когнітивних фрункцій людини, що виникає внаслідок захворювань або травм головного мозку. Хвороба Альцгеймера $€$ первинною дегенеративною деменцією, яка супроводжується постійним прогресуванням певних порушень і призводить до тотального недоумства. Серед основних клінічних проявів захворювання є: прогресуючі порушення вищих психічних фрункцій, а саме пам'яті, уваги і мислення, погіршення в некогнітивній сорері і поведінкової діяльності, які дезадаптують людину в соціальному, професійному та побутовому середовищі. Через порушення координації хворі обмежують свою рухову активність, через що ускладнюється протікання супутніх захворювань або погіршується загальне самопочуття хворого.

3 урахуванням основних та супутніх порушень у пацієнтів із хворобою Альцгеймера, у процесі дослідження нами було розроблено комплексну програму фрізичної терапії та ерготерапії, яка включала: ранкову гігієнічну гімнастику, лікувальну гімнастику, працетерапію, лікувальну дозовану ходьбу. Метою реабілітаційного втручання було: поліпшення фрізичного здоров'я та якості життя осіб похилого віку з хворобою Альцгеймера. Досягнення мети конкретизується у поставлених завданнях, серед яких: підвищення психоемоційного стану або зниження рівня перезбудження; підвищення рівня добової рухової 
активності; розвиток основних фрізичних якостей: загальної витривалості, м'язової сили, координаційних здібностей (орієнтація у просторі, рівновага) та збільшення амплітуди рухів у суглобах; уповільнення прогресування когнітивних порушень. Дослідження проводили упродовж 20182019 рр. на базі Комунальної установи Сумської обласної ради «Лебединський психоневрологічний інтернат», у якому прийняли участь 14 осіб похилого, серед них 9 жінок та 6 чоловіків віком від 65-66 років із хворобою Альцгеймера.

\section{Література}

1. Gasecki D, Kwarciany M, Nyka W. Hypertension, Brain Damage and Cognitive Decline [Hypertension, Brain Damage and Cognitive Decline]. Current Hypertension Reports. 2013; 15 (6): 547-58.

2. Бачинская НЮ. Лечение болезни Альцгеймера: современные возможности и перспективы [Treatment of Alzheimer's disease: current opportunities and prospects]. НейpoNews психоневрология и нейропсихиатрия []. 2013; 2: 1-7.

3. Богатирьова ДО, Мардаревич МГ. Хвороба Альцгеймера: тенденції поширення у світі [Alzheimer's disease: trends in the world]. Збірник наукових праць VIII Всеукраїнської науково-практичної конференції з міжнародною участю «Біологічні дослідження - 2017». 2017, 368 с.

4. Визначення віку, з якого особа може вважатися особою похилого віку: огляд міжнародного досвіду та національні практики [Determining the age from which a person can be considered an elderly person: overview of international experience and national practices]. [Internet]. 2018 Mar. [cited 2020 Feb 19]; Available from: https://www.prostir.ua/wp-content/ uploads/2018/12/ Огляд міжнародного досвіду. pdf .

5. Горбаль А, Горох $€$, Насрідінов Р, Процюк А. Дані для паліативної допомоги : міжнародний досвід, українська практика, стандарти, індикатори, оцінки [Data for palliative care: international experience, Ukrainian practice, standards, indicators, assessments]. Київ, 2018; 60 c.

6. Григорьева ВН, Ковязина МС, Тхостов АШ. Когнитивная нейрореабилитация больных с очаговыми поражениями головного мозга: учебное пособие [Cognitive neurorehabilitation of patients with focal brain lesions: a textbook]. Москва, 2006; 256 c.

7. Дедюхіна О, Білянський О. Особливості деменції в осіб похилого віку та застосування фізичної реабілітації [Features of dementia in the
Впровадження розробленої нами програми відбувалося упродовж п'яти місяців із дотриманням загальнодидактичних (активності, поступовості, доступності, наочності та ін.) і специфрічних принципів, та відповідно до функціональних можливостей пацієнтів (щадному та щадно-тренувальному рухових режимах).

Перспективи подальших досліджень полягають у перевірці едективності розробленої нами комплексної програми фрізичної терапії та ерготерапії в умова психоневрологічного інтернату.

elderly and the use of physical rehabilitation]. Спортивна наука України. 2015; 3(67): 9-14

8. Козьолкін ОА, Сікорська МВ, Візір IB, Нерянова ЮМ. Деменція, навчально-методичний посібник [Features of dementia in the elderly and the use of physical rehabilitation]. Запоріжжя, 2015; 90 c.

9. Крашений IE, Попов АО, Рамірез Х, Горріз ХМ. Використання методів кластеризації в системах нечіткого виводу для діагностики хвороби Альцгеймера на основі ПЕТ-зображень [The use of clustering techniques in fuzzy inference systems for the diagnosis of Alzheimer's disease based on PET images]. Биомедицинские приборы и системы. 2016; 2(91): 56-62.

10. Мудренко ІГ. Клінічні предиктори суїцидальної поведінки хворих з деменціями різних типів [Clinical predictors of suicidal behavior in patients with dementia of different types]. Журнал клінічних та експериментальних досліджень. 2018; 6(1): 89-96.

11. Мухін ВМ. Фізична реабілітація: підручник для студентів ВН3 фріз виховання і спорту [Physical rehabilitation: a textbook for students of higher education institutions education and sports]. Київ, 2010; 488 с.

12. Населення України. Імперативи демографрічного старіння [The population of Ukraine. Imperatives of demographic aging]. Київ, 2014; 288 с.

13. Пінчук |Я, Дудіна ЖГ, Степанова НМ. Міжнародний досвід надання паліативної допомоги хворим на тяжку деменцію [International experience in palliative care for patients with severe dementia]. Клінічна психіатрія. 2014; 2 (77): 89-95.

14. Романів ОП, Чорей ДВ. Особливості когнітивної реабілітації пацієнтів з деменцією [Features of cognitive rehabilitation of patients with dementia]. Економіка і право охорони здоров'я. 2018; 1 (7): 17-22. 